\title{
Soft Tissue Sarcoma of the Abdomen and Thoracic Visceral Organs pT4a TNM
}

\section{Finding v8}

National Cancer Institute

\section{Source}

National Cancer Institute. Soft Tissue Sarcoma of the Abdomen and Thoracic Visceral

Organs pT 4a TNM Finding v8. NCI Thesaurus. Code C136740.

Soft tissue sarcoma of the abdomen and thoracic visceral organs with multifocal involvement (two sites). (from AJCC 8th Ed.) 